\title{
Human Resources: Overview of the Company's reputation from weaknesses, strengths and challenges in a crisis
}

\author{
Chencho Dorji \\ Department of Management Development, Royal Institute of Management, Bhutan
}

\begin{abstract}
This article discusses the human resources of the company reputation review of the weaknesses, strengths, and challenges in the crisis. A company that has a good reputation will be more attractive to qualified prospective employees, get free mass media coverage so it doesn't require large advertising costs, and get other benefits that contribute to company profits. Steps are needed to be taken to overcome the crisis by analyzing the crisis in depth, systematically, informatively, and descriptively of the crisis that occurred through a neatly prepared report. HR development is generally more focused on the long-term needs of the organization. The results are indirect and can be measured in the long term.
\end{abstract}

Keywords: Human Resources, Company Reputation, Crisis

Received: August 12, 2020

Received in Revised: August 24, 2020

Accepted: August 27, 2020

\section{Introduction}

Human development or development is closely related to the improvement of the intellectual abilities needed to do a better job. Human resource development rests on the fact that every workforce needs better knowledge, expertise, and skills. Human resources or manpower, abbreviated as HR, is an ability that humans have (Tyson, 2014). Strictly speaking, the ability of every human being is determined by the power of thought and physical power (Carroll, 1993).

Dominguez (2012) states that the important role of human resources in a company's success is because the global economy requires innovation and flexibility to support the performance of a company. There is the influence of HR and its impact on company reputation (Hannon \& Milkovich, 1996).

The results of previous research are sometimes inconsistent with the results obtained, it is inconsistent with regard to HR accounting. Besides that, this article also contributes to readers by adding new knowledge about human resource accounting which can also be used as a reference.

In this article, there is no significant difference between theory and phenomena that occur. Both stated that companies with broader HR accounting disclosures would be able to provide a greater reputation for the company because better HR quality could make the quality aspects of the products produced will also be better and have an impact on increasing the company's reputation. The company's reputation is also an important factor for customers in making decisions on whether to use the products or services we sell. This article aims to discuss the human resources of the Company Reputation review of the weaknesses, strengths, and challenges in a crisis.

\section{HR Development}

HR development is generally more focused on the long-term needs of the organization (Jackson \& Schuler, 1990; Fenwick \& Bierema, 2008). The results are indirect and can be 
measured in the long term. Training is aimed at improving the work performance of the apparatus, while development is aimed at improving skills in jobs that have routine.

In terms of competency development, basically, the experience can be increased by providing opportunities in various positions, while technical competencies can be developed through education and training aimed at improving knowledge and skills. For behavioral competencies, development programs that can be carried out are through various training and individual development programs aimed at changing behavior, while organizational values that shape institutional competencies can be instilled through indoctrination.

\section{Strengths and Weaknesses}

The strength of this article is that this article provides several variables that can make it easier for writers to produce better research results than previous studies. While the weakness of this article is that the appraiser's subjectivity is still visible, because the social disclosure report is not presented explicitly so that it still requires the assessor's interpretation. a potentially favorable external situation to the organization.

Organizations that are in the same industry will generally feel benefited when faced with these external conditions. For example, there is a certain market segment where other players have not yet entered, in general, it will be an opportunity for any organization that has succeeded in seeing that market. internal organization in the form of competencies, capabilities, or resources owned by the organization, which can be used as an alternative to deal with opportunities and threats.

\section{Company Reputation}

Lewis \& Rayner (2003) defines reputation as a collection of past and current perceptions and beliefs that are realized by company stakeholders. Big-name products or company reputation are like two currencies that cannot be separated. One cannot be selected. Sometimes the Management Team is more focused on the success of their products, even though it is important to realize that the company's reputation is no less important for business.

Reputation is a concept in public relations (PR) that is difficult to define clearly. Reputation is an intangible asset that is difficult to measure and explain because reputation is not a visible product (Rindova, 2010). The existence of a good reputation can strengthen the company's position when dealing with competitors. Some circles consider the reputation the same as company image, while others say that reputation is different from image as well as cognitive theory in visual communication.

Reputation describes an organization's ability to generate value and provide benefits to stakeholders. In its formation, reputation is determined by several factors, namely financial performance, corporate governance and leadership practices, organizational compliance with applicable laws, customer satisfaction fulfillment, workplace culture, corporate social responsibility, communication, and crisis management.

Investment in human resources is not only the responsibility of one development sector, but also a multi-sector responsibility in an integral whole. In the most important sectors that directly contribute to the development of human resource capacity are education, improvement of nutrition and health, population programs, and sports coaching. However, of the various forms of human resource investment, education can be said to be the main catalyst for human resource development, assuming that the more educated a person is, the higher his awareness of health, political participation, and family planning, so that education can be considered as investment advice that is considered capable of increasing knowledge. , skills, and expertise of the workforce. 
Human resource management is the withdrawal, selection, development, maintenance, and use of human resources to achieve the goals of both individuals and organizations. The ability of an organization is highly dependent on the availability and ability of Human Resources (HR) in carrying out a task or job. Human resources, in this case, employees, have knowledge and skills in the areas of their responsibility. Because this will encourage the achievement of organizational goals more quickly, effectively and efficiently, so that by itself the organization will always be ready to face and adapt to any changes that exist, especially those related to efforts towards organizational development. On the other hand, an organization that is not supported by adequate employee capabilities will be seriously threatened by its existence, for example, a public organization will not be able to provide satisfactory services to the community if its employees do not understand and master its main duties and functions.

\section{Maintain the company's reputation in the face of a crisis}

Reputation includes the perceptions of stakeholders regarding all aspects of the organization. They propose a simple theory about how to build a good reputation. The theory states that "a good reputation can be obtained by an organization if the organization succeeds in meeting or exceeding the expectations of its stakeholders, while a bad reputation will be obtained by the organization if they cannot meet the expectations of stakeholders.

Image is the way how other parties view a company, a person, a committee, or an activity. Every company has an image as many as the number of people looking at it. Various corporate images come from corporate customers, potential customers, bankers, company staff, competitors, distributors, suppliers, trade associations, and customer movements in the trade sector who have views of the company.

Apart from human resource capacity, another thing that affects the reliability and timeliness of the Company's financial reports is the use of information technology. In the area of regional corporate finance, there is already a greater attention to assessing the feasibility of corporate management practices which include improvements to the management accounting system, financial accounting system, financial planning and development, supervision and inspection systems as well as various financial implications for the policies implemented by the Company. Regional companies are currently facing pressure to be more efficient, taking into account economic and social costs as well as the negative impact of their activities.

In a condition that increasingly demands reliable public services to catch up with neighboring countries, corporate human resources must be able to show their ideal figure. As the implementer of Company policy, ASN must first solve its own problems so that it can become a smart machine that is not burdensome but provides solutions. This is where the apparatus is able to help solve the nation's internal problems in order to further increase the nation's competitiveness. This reason is the main requirement of the need for ASN restructuring thoughts.

Restructuring of corporate human resources is restructuring the existence of the apparatus in carrying out their duties and functions properly (Torbert, 1987). This effort is considered difficult and requires a bold breakthrough in taking steps for change. In the definition of the Office of the Ministry for Administrative Reform, the restructuring is a package in an effort called bureaucratic reform.

Because the image is in the minds of the community, one of the things that an organization must do is to make various efforts so that people do not have a wrong perception of the organization which then creates a negative image. If a negative image has been formed in the minds of the public, it will certainly be very detrimental to the organization. For this reason, 
the image of the organization must be considered in such a way so that people's perceptions do not deviate far from what is expected. Image is only a true picture of someone about something that of course we can form. But the image we are trying to form must be in accordance with reality (reality) and no attempts to deceive should be made. For example, something that is actually not good is described as being good. Lies, in the end, will not bring good, let alone improve the image, what happens is, on the contrary, the image will be damaged and destroyed. So image (image) is reality, therefore the development and improvement of images must be based on reality.

The company's reputation needs to be considered in choosing a share. The better the company's reputation in the eyes of the market, the more desirable the company's products/services are to be used. The greater the level of market interest in products/services, the greater the opportunity for the company to increase sales. And in the end, the bigger the company is consistent in printing profit growth.

A company with a good reputation will be highly rated by the market. Products/services will also be highly valued, because reputation has its own value. Same thing with stocks. Reputable company stocks will certainly be appreciated by the market higher. This can be seen from the issuer's PER value, which is quite high even though its performance is normal.

One of the efforts to improve company performance is to boost sales and competitiveness. These two things are closely related to the company's reputation and consumer desires. The company tries to gain the trust of consumers. However, on the other hand, shareholders want income. To bridge this requires a reputation so that it is known in the world. The Reputation Institute, a global consulting firm based in New York, recently ranked 100 companies in the world that have successfully built their international name.

The first stage is a determination to find out a crisis problem. Identifying the factors causing the crisis serves to determine whether public relations (PR) or the company can handle the crisis that occurred immediately or not. If the crisis is difficult to overcome, wasting time, effort, and money, PR can see another aspect of the crisis which has problems that have not been previously imagined, namely usually a company that is hit by a crisis or disaster is accompanied by the appearance of other unexpected problems. Therefore, the main factors causing the significant crisis must first be identified, to take action or countermeasures or a way out appropriately, quickly, and correctly.

Steps are needed to be taken to overcome the crisis. This step is obtained by analyzing the crisis in a deep, systematic, informative and descriptive manner of the crisis that occurred through an in-depth reporting. One way to analyze is the $5 \mathrm{~W}+1 \mathrm{H}$ formula, which is to analyze through several questions asked to determine the response to a crisis.

A company that has a good reputation will be more attractive to qualified prospective employees, get free mass media coverage so it doesn't require large advertising costs, and get other benefits that contribute to company profits. Thus, reputation needs to be managed as well as possible in order to obtain these benefits.

\section{Conclusion}

Company image and reputation includes the perceptions of stakeholders regarding all aspects of the organization. They propose a simple theory about how to build a good reputation. The theory states that "a good reputation can be obtained by an organization if the organization succeeds in meeting or exceeding the expectations of its stakeholders, while a bad reputation will be obtained by an organization if they cannot meet the expectations of its stakeholders. It takes steps that need to be taken to overcome the crisis, namely analyzing the crisis in a deep, systematic, informative and descriptive way. 


\section{References}

Carroll, J. B. (1993). Human cognitive abilities: A survey of factor-analytic studies. Cambridge University Press.

Domínguez, M. A. Á. (2012). Company characteristics and human resource disclosure in Spain. Social responsibility journal.

Tyson, S. (2014). Essentials of human resource management. Routledge.

Lewis, D., \& Rayner, C. (2003). Bullying and human resource management: a wolf in sheep's clothing?. In Bullying and emotional abuse in the workplace: International perspectives in research and practice (pp. 370-382). Taylor \& Francis.

Jackson, S. E., \& Schuler, R. S. (1990). Human resource planning: Challenges for industrial/organizational psychologists. American psychologist, 45(2), 223.

Fenwick, T., \& Bierema, L. (2008). Corporate social responsibility: issues for human resource development professionals. International Journal of training and Development, 12(1), 24-35.

Torbert, W. R. (1987). Managing the corporate dream: Restructuring for long-term success. Homewood, IL: Dow Jones-Irwin.

Hannon, J. M., \& Milkovich, G. T. (1996). The effect of human resource reputation signals on share prices: An event study. Human Resource Management, 35(3), 405-424.

Rindova, V. P., Williamson, I. O., \& Petkova, A. P. (2010). Reputation as an intangible asset: Reflections on theory and methods in two empirical studies of business school reputations. Journal of Management, 36(3), 610-619. 